Reprod. Nutr. Dévelop., 1984, 24 (4), 461-468.

\title{
Sperm transport into the oviducts of heifers mated early in oestrus
}

\author{
I. WILMUT, R. H. F. HUNTER $\left({ }^{*}\right)$
}

$A R C$, Animal Breeding Research Organisation, Dryden Field Laboratory, Roslin, Midlothian EH25 9PS, U.K.

(*) School of Agriculture, University of Edinburgh, West Mains Road, Edinburgh EH9 3JQ, U.K.

Summary. An estimate has been made of the time required for a population of spermatozoa capable of fertilising the egg to be established in the oviducts of heifers mated early in oestrus. During a general or local anaesthetic, the caudal isthmus of the oviduct was ligated and sectioned $6,8,10$ or $12 \mathrm{hr}$ after mating. The proportion of eggs fertilised as judged 2-4 days later was very low if ligation was carried out after $6 \mathrm{hr}(1$ of 11) and only approached normal levels of $85 \%$ or more following ligation at $12 \mathrm{hr}$ (7 of 10). These results suggest that the population of spermatozoa capable of fertilisation is established in the oviduct over a period of not less than 6 hours and probably more than $12 \mathrm{hr}$. These results contrast with reports of rapid transport of spermatozoa to the oviduct in a period of minutes.

\section{Introduction.}

The development of techniques for the dilution, deep-freezing and artificial insemination of bull semen has made a major contribution to cattle breeding and production. Although the procedures used are commercially acceptable, they could be improved. Fertilisation failure may occur in up to $15 \%$ of apparently healthy females and in up to $40 \%$ of animals that have failed to conceive after several inseminations (Tanabe and Casida, 1949 ; Tanabe and Almquist, 1953 ; Kidder et al., 1954 ; Bearden, Hansel and Bratton, 1956 ; Boyd et al., 1969). Furthermore, insemination at an inappropriate time relative to ovulation is known to reduce fertility (Trimberger, 1948 ; Deas, 1970 ; MacMillan and Watson, 1975a, b ; Robbins et al., 1978; Foote, 1979), partly because the proportion of eggs fertilised is reduced, but also because those eggs fertilised after a postovulatory delay are more likely to die during embryonic development (Casida, 1950 ).

The present paper describes an experiment carried out as part of an investigation into sperm transport in cattle with the hope that an understanding of 
the pattern of transport will lead to an improvement in methods and timing of insemination (Hunter, 1984). Previous studies in this species have used counts of spermatozoa in flushings (VanDemark and Moeller, 1951), smears (Dauzier, 1958) and histological preparations (Thibault, Gerrard and Heyman, 1973) to assess the movement of spermatozoa through the reproductive tract. In some reports, emphasis has been placed on a phase of very rapid transport immediately after mating or A.I. which was capable of moving even immotile spermatozoa to the ampulla region of the oviduct within minutes (VanDemark and Moeller, 1951 ; VanDemark and Hays, 1954) while others described a progressive increase in sperm numbers in the oviduct over 8 to $18 \mathrm{hr}$ (Dauzier, 1958 ; Thibault et al., 1973). However, none of these studies provided information as to whether the spermatozoa were capable of fertilising the egg. In the present experiment, the technique of post coital ligation of the oviduct has been used to determine how soon a competent population of spermatozoa is established in the oviduct, if mating occurs early in heat. A preliminary report of some of the observations has been published (Hunter and Wilmut, 1983).

\section{Materials and Methods.}

Animals. - The experiment was carried out in two parts from May to October 1981 and during the same period in 1982. Cross-bred heifers weighing approximately $350 \mathrm{~kg}$ were kept in groups of 10 to 20 at ABRO, Blythbank, Peeblesshire (1981) or Field Laboratory, Roslin, Midlothian (1982). The oestrous cycles of each group were synchronised by administration of two injections of $500 \mu \mathrm{g}$ cloprostenol (Estrumate, ICl Ltd.) with an 11 day interval between the treatments. As the time of the second oestrus after the injections approached, the heifers were housed in a deep-bedded court in groups of 10 to 15 . The animals were fed according to commercial practice.

Experimental procedure. - In order to detect the onset of oestrus, the animals were observed frequently between 06.30 and $21.00 \mathrm{hr}$ in 1981 and 08.00 and $22.00 \mathrm{hr}$ in 1982 . Service was allowed as soon as possible after observation of oestrous behaviour and always within $8 \mathrm{hr}$ of this time. Animals observed in oestrus at the first inspection in the morning were always served immediately. Each animal was served once by a bull of proven fertility.

Surgical procedures. - Surgery was carried out to section and ligate an oviduct $6,8,10$ or $12 \mathrm{hr}$ after mating. The reproductive tract was exposed either through the flank while the animal was subjected to local anaesthetic (1981) or through a mid-ventral incision while the animal was under general anaesthesia (1982). The procedures for the flank approach have been described (Hunter and Wilmut, 1983).

Animals to be subjected to general anaesthesia were deprived of food and water from the time of mating until the completion of surgery. Anaesthesia was induced with sodium thiopentone (Intraval, May and Baker, Ltd.) and maintained with a mixture of oxygen, nitrous oxide and halothane (Fluothane, ICl Ltd.). After 
shaving and cleaning the skin, the reproductive tract was exposed through a midventral incision. The ovaries were palpated to identify the pre-ovulatory follicle and the region of the utero-tubal junction brought to the surface on the side of the expected ovulation.

In all cases, two ligatures of braided silk (2.5 metric, Ethicon Ltd.) were placed around the caudal isthmus immediately adjacent to the utero-tubal junction. The ligatures were approximately $2 \mathrm{~mm}$ apart and the oviduct was transected between the ligatures. Care was taken to avoid blood vessels and to minimise the handling of the reproductive tract.

Procedure at autopsy. - After recovering from the anaesthesia the heifers were isolated in small indoor pens until slaughter 2 to 4 days after surgery. The heifers were killed at Edinburgh City Abattoir and the tract returned to the laboratory within $30 \mathrm{~min}$. The uterus and oviducts were dissected from the ligments and each oviduct flushed, repeatedly if necessary, with warm Eagle's medium (Flow Laboratories). The eggs were examined by phase contrast microscopy. They were mounted whole between a slide and a coverslip and examined at $\times 400$ before being fixed for $24-48 \mathrm{hr}$ in acetic acid-ethanol $11: 3$ by volume) and stained with $1 \%$ orcein in $45 \%$ aqueous acetic acid (Chang, 1952). A note was made of the number of spermatozoa attached to or embedded in the zona pellucida and whether or not the egg had been fertilised.

Statistical analysis. - The effect of treatment on the proportion of eggs fertilised was analysed by fitting a linear model and allowing for binomial errors with a logit link function (GLIM computer program ; Royal Statistical Society).

\section{Results.}

Twenty-nine animals were operated on through the flank and eggs were recovered from 19 heifers at autopsy $(66 \%)$. Among the other 10 heifers, two had not ovulated at the time of slaughter $(2$ of $29 ; 7 \%)$, one had ovarian adhesions and hydrosalpinx, and in a fourth case the reproductive tract was so taut at the time of surgery that it was not possible to place ligatures on the oviduct. In the other 6 cases there was no apparent cause for failure to recover an egg despite repeated flushing.

Eggs were recovered from 24 of the 35 heifers operated on under general anaesthetic (69\%). Among the other 11 heifers, 6 had not ovulated at the time of slaughter $(6$ of $35 ; 17 \%)$, one had hydrosalpinx and infection in the uterus and in an eighth case the reproductive tract was oedematous at the time of surgery and found to be full of clear fluid at slaughter. Although no egg was found in 3 other cases, there was no apparent abnormality of the tract.

The proportion of eggs fertilised was greatly influenced by the interval from mating to surgery (table 1). The trends in the proportion of eggs fertilised were not significantly different after use of the two surgical approaches and the results will be considered together. If the oviduct was ligated and cut six hours after mating only one of eleven eggs was fertilised and no more than one accessory spermatozoon was found. By contrast, as the interval from mating to surgery 
increased to 8,10 and $12 \mathrm{hr}$, the proportion of eggs fertilised increased to 4 of 10 $(40 \%), 5$ of $12(42 \%)$ and 7 of $10(70 \%)$ respectively. The increase with time was significant $(P<0.05)$. There was a comparable increase in the number of accessory sperm observed, although the number was very variable.

TABLE 1

The proportion of eggs fertilised after the caudal isthmus was ligated and sectioned $6,8,10$ or $12 \mathrm{hr}$ after mating.

\begin{tabular}{|c|c|c|c|c|c|c|c|c|c|}
\hline \multirow{2}{*}{$\begin{array}{c}\text { Interval } \\
\text { from mating } \\
\text { to surgery } \\
(\mathrm{hr})\end{array}$} & \multicolumn{3}{|c|}{$\begin{array}{l}\text { Flank approach. } \\
\text { Number of eggs }\end{array}$} & \multicolumn{3}{|c|}{$\begin{array}{l}\text { Mid ventral approach. } \\
\text { Number of eggs }\end{array}$} & \multicolumn{3}{|c|}{$\begin{array}{l}\text { Overall results. } \\
\text { Number of eggs }\end{array}$} \\
\hline & Recovered & Fertilised & $\begin{array}{l}\text { No of } \\
\text { sperm } \\
\left({ }^{*}\right)\end{array}$ & Recovered & Fertilised & $\begin{array}{l}\text { No of } \\
\text { sperm } \\
\left({ }^{*}\right)\end{array}$ & Recovered & Fertilised & $\%$ \\
\hline 6 & 7 & 0 & $\begin{array}{c}0.2 \\
(0-1)\end{array}$ & 4 & 1 & $\begin{array}{c}0.3 \\
(0-1)\end{array}$ & 11 & 1 & 9 \\
\hline 8 & 6 & 3 & $\begin{array}{c}0.2 \\
(1-2)\end{array}$ & 4 & 1 & $\begin{array}{c}0.5 \\
(0-2)\end{array}$ & 10 & 4 & 40 \\
\hline 10 & - & - & - & 12 & 5 & $\begin{array}{l}2.6 \\
(2-4)\end{array}$ & 12 & 5 & 42 \\
\hline 12 & 6 & 5 & $\begin{array}{l}(4.5) \\
(1-11)\end{array}$ & 4 & 2 & $\begin{array}{l}2.5 \\
(1-4)\end{array}$ & 10 & 7 & 70 \\
\hline
\end{tabular}

(*) Mean number of spermatozoa attached to or embedded in the zona pellucida (the range shown in brackets).

\section{Discussion.}

In cattle mated early in oestrus, a population of spermatozoa capable of fertilising the eggs is only established in the oviduct over a period of several hours. These results contrast with reports of a phase of very rapid transport during which spermatozoa are transported to the oviduct in a period of minutes. Under the present experimental circumstances, the proportion of eggs fertilised was very small if the oviduct was cut and separated from the uterus $6 \mathrm{hr}$ after mating, but the proportion approached normal levels when the surgery was carried out $12 \mathrm{hr}$ after mating. Similar results have been obtained in sheep, in which species no eggs were fertilised after ligation at 4 or $6 \mathrm{hr}$, but $30 \%$ and $100 \%$ were fertilised following section 8 and $10 \mathrm{hr}$ after mating, respectively (Hunter, Nichol and Crabtree, 1980).

These results suggests that in cattle the process of establishing the functional population in the oviduct had begun by $6 \mathrm{hr}$ after mating, but was incomplete even a further $6 \mathrm{hr}$ later. The rate of loss of viable spermatozoa from the oviduct could also influence the proportion of eggs fertilised. It is possible that spermatozoa capable of fertilisation were present in the oviduct $6 \mathrm{hr}$ after mating, but were lost subsequently into the peritoneal cavity. Nevertheless, serial histological studies suggest a negligible passage of spermatozoa into the ampulla early in oestrus (Thibault et al., 1973). 
While eggs were recovered from a similar proportion of the heifers in the two groups, there was a suggestion that the cause of failure was different in the two groups. Whereas ovulation had not occurred by the time of slaughter in 6 of the 35 heifers subjected to general anaesthesia $(17 \%)$ all but 2 of the $29(7 \%)$ animals given local anaesthesia had ovulated by this time. By contrast, a greater proportion of the eggs shed were recovered after surgery under general anaesthetic ( $83 \%$ cf. $70 \%$ ). The two surgical approaches employed in this study both have their limitations. General anaesthesia early in oestrus might affect the time of ovulation by inhibiting the release of gonadotrophin (Clarke and Doughton, 1983) whereas the delay in ovulation in some heifers given local anaesthetic may reflect an influence of sedative or of stress on gonadotrophin release (Stoebel and Moberg, 1982). Furthermore the exteriorisation of the uterotubal junction through the flank required considerable force in some heifers and this could have caused displacement of spermatozoa along the reproductive tract. The fact that comparable results were obtained in the two groups suggests that if these artefacts did occur, they were not sufficient to distort the underlying mechanisms. However, it should be appreciated that there were not enough animals in the two groups to allow a sensitive test of the effect of experimental method on the proportion of eggs fertilised.

These observations provide a new light in which to interpret studies of sperm transport in cattle made by counting spermatozoa in smears or in sections. A very rapid transport has been reported after the recovery of one or two spermatozoa from the oviduct within 2.5 to $3.3 \mathrm{~min}$ of mating or deep intracervical insemination (VanDemark and Moeller, 1951 ; VanDemark and Hays, 1954). As the excised tract was bathed in warm saline until an examination was made, there would have been a great risk of contamination. By contrast, counts of spermatozoa in smears (Dauzier, 1958) and sections of the tract (Thibault, 1973; Thibault et al., 1973) revealed a progressive increase in the numbers present in the oviduct during the period studied (2 to $18 \mathrm{hr}$ ). While the present results do not preclude the possibility of a phase of rapid transport, they do emphasise that any spermatozoa transported to the oviduct within minutes of mating early in oestrus are not capable of fertilising the egg which is ovulated approximately 28 hours later.

A phase of rapid transport has been described in two other species in which semen is deposited in the vagina during mating : the sheep (Mattner and Braden, 1963) and the rabbit (Overstreet and Cooper, 1978a). In both of these studies, great care was taken to prevent contamination of fluid from one region with spermatozoa from a different segment of the reproductive tract. These observations contrast with the respective estimates of $3 \mathrm{hr}$ and $10 \mathrm{hr}$ as the time required for a population of spermatozoa capable of achieving normal fertilisation to be established in the oviducts of rabbits (Adams, 1956) and ewes mated early in oestrus (Hunter et al., 1980).

The phenomenon of very rapid sperm transport has been investigated most thoroughly in rabbits, in which species it was found to be initiated by components of the seminal plasma (Overstreet and Tom, 1982). Rapid transport was not dependent upon motility of the spermatozoa, and was inhibited by the $\alpha$-adre- 
negic blocking agent, phenoxybenzamine, demonstrating the predominant role of the female tract in very rapid transport. As rapidly transported spermatozoa are apparently not involved directly in fertilisation in any of these species, there is a need for research to define their functions. It has been suggested that they may be local messengers acting to coordinate movement of the reproductive tract (Overstreet, 1983). There is also a need for further research in sheep and cattle to re-examine the extent of very rapid transport and to define the mechanism if it occurs.

In sheep there is an increased rate of movement of spermatozoa to the oviduct if Al or mating occurs late in oestrus (Killeen and Moore, 1970 ; Hunter et al., 1982), and evidence that spermatozoa move from the isthmus to the ampulla at the time of ovulation (Hunter et al., 1982 ; Hunter and Nichol, 1983). The present observations provide a framework within which to analyse these later stages of sperm transport in cattle.

Reçu en décembre 1983. Accepté en mars 1984.

Acknowledgements. - We are grateful to the Agricultural Research Council and the School of Agriculture for meeting the costs of the experiment. The statistical analysis was carried out by J. Woolliams. We are also indebted to C. Manson, R. Nichol, M. Thomson and the staff on the farms for assistance with the experiment.

Résumé. Transport des spermatozoïdes dans les oviductes de génisses accouplées au début de l'cestrus.

Le temps nécessaire à une population de spermatozoïdes aptes à la fécondation pour s'établir dans les oviductes de génisses accouplées au début de l'œstrus a été évalué. Après anesthésie générale et locale, l'isthme caudal de l'oviducte a été ligaturé et sectionné 6,8 , 10 ou $12 \mathrm{~h}$ après l'accouplement. La proportion d'œufs fécondés appréciée 2 à 4 jours plus tard est très faible si la ligature a été mise en place à $6 \mathrm{~h}$ (1 sur 11) et n'approche un niveau normal de $85 \%$ que si la ligature a été mise en place à $12 \mathrm{~h}$ (7 sur 10).

Ces résultats suggèrent qu'il faut au moins $6 \mathrm{~h}$ et sans doute plus de $12 \mathrm{~h}$ à une population de spermatozoïdes fécondants pour s'établir dans l'oviducte. Ils sont incompatibles avec un transport des spermatozoïdes dans l'oviducte réalisé en quelques minutes.

\section{References}

ADAMS C. E., 1956. A study of fertilization in the rabbit : the effect of post-coital ligation of the fallopian tube or uterine horn. J. Endocr., 13, 296-308

BEARDEN H. J., HANSEL W., BRATTON R. W, 1956. Fertilization and embryonic mortality rates of bulls with histories of either low or high fertility in artificial breeding. J. Dairy Sci., 39, 312 318.

BOYD H., BACSICH P., YOUNG A., McCRACKEN J. A., 1969. Fertilization and embryonic survival in dairy cattle. Br. vet. J., 125, 87-97.

BRADEN A. W. H., 1953. Distribution of sperms in the genital tract of the female rabbit after coitus. Aust. J. biol. Sci., 6, 693-705.

CASIDA L. E., 1950. The repeat breeder cow. Vlaams Diergeneesk. Tijdschr., 19, 273-283. 
CLARKE I. J., DOUGHTON B. W., 1983. Effect of various anaesthetics on resting plasma concentration of luteinizing hormone, follicle-stimulating hormone and prolactin in ovariectomised ewes. J. Endocr., 98, 79-89.

CHANG M. C., 1952. Fertilizability of rabbit ova and the effects of temperature in vitro on their subsequent fertilisation and activation in vivo. J. exp. Zool., 621, 351-382.

DAUZIER I., 1958. La montée des spermatozoïdes dans le tractus génital femelle. Ann. Zootech., 7. 290-301.

DEAS D. W., 1970. The timing of insemination. Vet. Rec., 86, 450-451.

FOOTE R. H., 1979. Time of artificial insemination and fertility in dairy cattle. J. Dairy Sci., 62, 355 358.

HUNTER R. H. F., 1984. Towards $100 \%$ fertilisation in inseminated cows with particular reference to the site of sperm storage. Anim. Breed. Abstr., 52, 1-5.

HUNTER R. H. F., BARWISE L., KING R., 1982. Sperm transport, storage and release in the sheep oviduct in relation to the time of ovulation. Br. vet. J., 138, 225-232.

HUNTER R. H. F., NICHOL R., 1983. Transport of spermatozoa in the sheep oviduct: preovulatory sequestering of cells in the caudal isthmus. J. exp. Zool., 228, 121-128.

HUNTER R. H. F., NICHOL R., CRABTREE S. M., 1980. Transport of spermatozoa in the ewe : Timing of the establishment of a functional population in the oviduct. Reprod., Nutr., Dévelop., 20, 1869-1875.

HUNTER R. H. F., WILMUT I., 1983. The rate of functional sperm transport into the oviducts of mated cows. Anim. Reprod. Sci., 5, 167-173.

KILLEEN K. D., MOORE N. W., 1970. Transport of spermatozoa and fertilisation in the ewe following cervical and uterine insemination early and late in oestrus. Aust. J. biol. Sci., 23, 1271-1277.

KIDDER H. E., BLACK W. G., WILTBANK J. N., ULBERG L. C., CASIDA L. E., 1954. Fertilization rates and embryonic death rates in cows bred to bulls of different levels of fertility. $J$. Dairy Sci., 37, 691-697.

MacMILLAN K. L., WATSON J. D., 1975a. Factors influencing A. B. conception rates. V. Cow age and stage of oestrus at insemination. N. Z. J. exper. Agric., 3, 29-33.

MacMILLAN K. L., WATSON J. D., 1975b. Fertility differences between groups of sires relative to the stage of oestrus at the time of insemination. Anim. Product., 21, 243-249.

MATTNER P. E., 1963. Spermatozoa in the genital tract of the ewe. II. Distribution after coitus. Aust. J. biol. Sci., 16, 688-694.

MATTNER P. E., BRADEN A. W. H., 1963. Spermatozoa in the genital tract of the ewe. I. Rapidity of transport. Aust. J. biol. Sci., 16, 473-487.

OVERSTREET J. W., 1983. Transport of gametes in the reproductive tract of the female mammal, 499-543. In : HARTMAN J. F., Mechanism and control of animal fertilization. Acad. Press, New York.

OVERSTREET J. W., COOPER G. W., 1978a. Sperm transport in the reproductive tract of the female rabbit : I. The rapid transit phase of transport. Biol. Reprod., 19. 101-114.

OVERSTREET J. W., COOPER G. W., 1978b. Sperm transport in the reproductive tract of the female rabbit : II. The sustained phase of transport. Biol. Reprod., 19, 115-132.

OVERSTREET J. W., TOM R. A., 1982. Experimental studies of rapid sperm transport in rabbits. J. Reprod. Fert., 66, 601-606.

QUINLIVAN T. D., ROBINSON T. J., 1969. Numbers of spermatozoa in the genital tract after artificial insemination of progestagen treated ewes. J. Reprod. Fert., 19, 13-86.

ROBINS R. K., SULLIVAN J. J., PACE M. M., ElLIOTT F. I., BARTLETT D. E., PRESS P. J., GRACE W. R., 1978. Timing the insemination of beef cattle. Theriogenology, 10, 247-255.

STOEBEL D. P., MOBERG G. P., 1982. Repeated acute stress during the follicular phase and the luteinizing hormone surge of dairy helters. J. Darry Scl., 65, 92-96.

TANABE T. Y., ALMQUIST J. O., 1953. Some causes of infertility in dairy heifers. J. Dairy Sci., 36, 586 (Abstr.).

TANABE T. Y., CASIDA L. E., 1949. The nature of reproductive failure of cows of low fertility. J. Dairy Sci., 32, 237-246.

THIBAULT C., 1973. Sperm transport and storage in vertebrates. J. Reprod. Fert., (Suppl.), 18, 3953. 
THIBAULT C., GÉRARD M., HEYMAN Y., 1973. Transport et survie des spermatozoïdes chez la vache, 343-356. In: E. S. E. HAFEZ, C. THIBAULT. Sperm transport, survival and fertilising ability. INSERM, Paris.

TRIMBERGER G. W., 1948. Breeding efficiency in dairy cattle from artificial insemination at various intervals before and after ovulation. Res. Bull. 153, Univ. Nebraska Coll. Agric., Agric. Exper. Stat., Lincoln, Nebraska.

VanDEMARK N. L., HAYS R. L., 1954. Rapid sperm transport in the cow. Fertil. Steril., 5, 131-137.

VanDEMARK N. L., MOELLER A. N., 1951. Speed of spermatozoan transport in reproductive tract of estrous cow. Am. J. Physiol., 165, 674-679. 